\title{
The Impact of Private Universities' Websites Services' Quality on the Reputation in Jordan (An Applied Study)
}

\author{
Ali Falah Al-zoubi ${ }^{1}$, Mohammad AlShoura ${ }^{2} \&$ Ayman Oudh $^{3}$ \\ ${ }^{1}$ Associate Prof of Marketing, Faculty of Business, Marketing Department, Arab Amman University, Jordan \\ ${ }^{2}$ Associate Prof of Marketing, Medill East University, Jordan \\ ${ }^{3}$ Zaytoonah University, Jordan
}

Correspondance: Ali Falah Al-Zoubi, Associate Prof of Marketing, Faculty of Business, Marketing Department, Arab Amman University, Amman, Jordan.

Received: November 14, 2017

Accepted: December 11, 2017 Online Published: December 19, 2017

doi:10.5539/ibr.v11n1p133

URL: https://doi.org/10.5539/ibr.v11n1p133

\begin{abstract}
This study aimed to grasp the impact of services quality of the Jordanian private universities' websites, on the reputation of these universities. The variables of website quality was relied on through the class of the website design in terms of comprehensiveness and attractiveness, the information quality in relation to its currentness and accuracy, and the services' quality for its reliability and responsiveness. The reputation variables consisted of; admiration, respect, and satisfaction. The study population consists of students at; Amman Arab University, Al Israa Uni versity, Zaytoonah Uni versity, Jadraa Uni versity, Jarash University and Princess Sumaya Uni versity for Technology, which all are Jordanian private universities in Amman and Irbid. The number of females and males students were (28512) students A sample of (600) Sekeran students was selected, Some of the most important conclusions the study found are; Jordanian uni versities have a good reputation, students are highly reverence and admire their universities. Although the information's quality provided by universities' websites was not to the aspirational level of the of the students, the design quality was at a good level, and the study also showed, that there is an impact on the reputation of the universities, due to their websites quality. The study presented recommendations, not limited to, but some of which are; the need to improve both qualities of services and information at the websites of Jordanian private universities.
\end{abstract}

Keywords: websites, quality of services, reputation, private universities, Jordan

\section{Introduction}

The information revolution has opened up new opportunities for private university education sector in Jordan, intensifying competition methods and ways, where by universities are trying to maintain their market share, through providing a high quality services at low cost, which will contribute to the improvement of reputation, and increases the turnouts of students.To achieve this goal, universities have begun to adopt modern methods of Internet and information technology, by establishing websites that provides integrated and high quality services, which will contribute to the improvement of its image before the interested individuals.

With the development of the concept of quality, and the spread of information technology, the interest in the vertical expansion arises in the provision of university services, through raising the level of service efficiency and quality. In addition, the interest in the quality of universities' we bsites arises, for it is considered one of the most influential factors in improving reputation and attracting students. The interest in the quality has become a main concern in all areas, due to the global competitiveness where the best endure, and eventually led to the interest for websites quality, and the services that it provides. However, websites quality is not an easy sphere, because the criteria that determine the websites quality varies, depending on the site and the nature of the services that it is providing. Out of this, the present study came to understand the impact of Jordanian private universities' websites upon the improvement of their reputation.

\section{The General Framework of the Study}

\subsection{The Study's Problem}

The study's problem lies in the reputation 'slow level of Arab Universities, including Jordanian ones compared 
with International Universities. King Saud University which was among the first 500 International Universities In the 2016 world rankings, was ranked at (315) (www.webometrics.info), and in the annually conducted evaluation of the universities, not a Jordanian university can be found at an advanced level. This evaluation process is conducted according to the information and services available on the Websites of the Universities, which means the importance of these Websites as an essential source of evaluation, which is expected to affect the reputation of these Universities.

\subsection{The Study's Questions}

Based on the study's problem, the main question of the study presented is; what is the effect of Jordanian private universities' websites quality, on the reputation of these universities? In addition, of that, the following questions branches:

1. What is the effect of website design's quality (comprehensiveness, attractiveness) on the reputation of Jordanian private universities?

2. What is the effect of website information's quality (currentness and accuracy), on the reputation of private Jordanian universities?

3. What is the effect of the website services quality (reliability, responsiveness) on the reputation of Jordanian private universities?

\subsection{The Study's Importance}

The study's importance is; that it is an applied study, which deals with an important subject, namely the reputation of private universities in Jordan, and the effect of websites quality on strengthening them and this importance can be summarized through the following:

1. The importance of E-services provided by private universities' websites for students and the general public.

2. The importance of the higher education sector in Jordan, as it is a broad, developing and highly sector competitive.

3. E-services is a global direction characterized by growth, especially in light of the high cost of collecting information, and the increasing need to invest time in a way that increases efficiency and saves costs.

4. The scarcity of previous studies on the subject, especially locally and in the Arab region (as far as both researchers knowledge).

\subsection{The Study's Objectives}

The study aims to identify the influential correlation between the quality of E- services of the Jordanian private universities' websites and the reputation of these universities. This objective is branching into the following:

1 . To acknowledge the role of the website design quality in terms of its comprehensiveness, attractiveness, and their impact on the reputation of Private Universities in Jordan.

2. Comprehend the role of the quality of the information available at the websites in relation to its currentness and accuracy, and its impact on the reputation of Private Universities in Jordan.

3. To grasp the role of service quality regarding reliability, responsiveness, and its impact on the reputation of Private Universities in Jordan.

4. Introduce recommendations, hoping that it will contribute to the improvement of the websites' quality of the Private Universities in Jordan, which in turn will increase their competitiveness and elevate their reputation in the Arab region and regionally.

\subsection{Model and Variables of the Study}

This study contains two types of variables and they are:

The independent variable; which is the services quality of the Websites and its indicators.

The dependent variable, and it is; the reputation of the Higher Education Organizations, and its dimensions. The following figure gives an illustration of this. 


\begin{tabular}{|l|}
\hline Dependent Variables: \\
\hline The reputation and indicators of \\
higher education organizations are: \\
-Admiration. \\
- Respect. \\
-satisfaction. \\
\\
\end{tabular}

Source: (Authors, 2017)

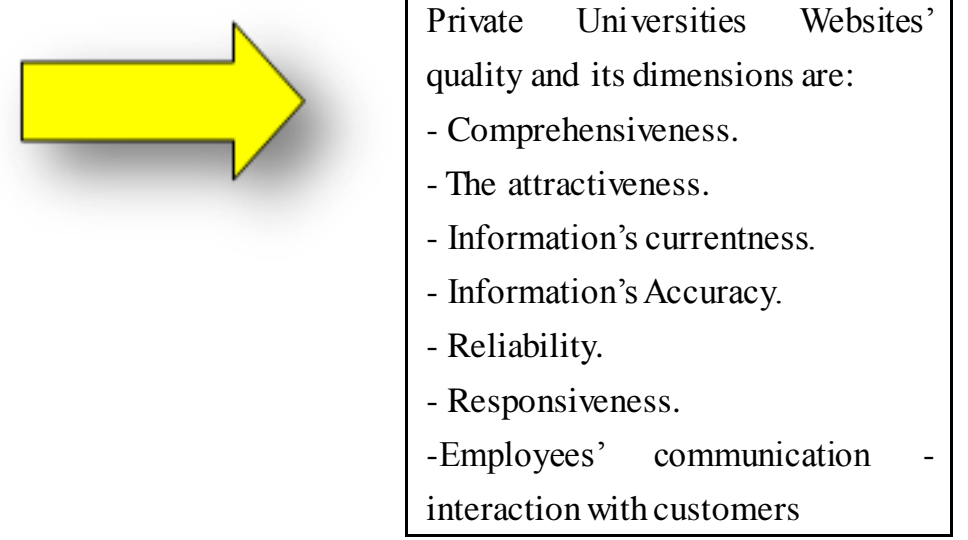

\subsection{The Study's Hypotheses}

Figure 1. The Model of the Study

\section{The study's main hypothesis}

Ho1: There is no effect of statistical significant at the level of $(\boldsymbol{\alpha} \leq \mathbf{0 . 0 5})$ for The quality of website in terms of its dimensions; (quality of website design, quality of information, quality of services), on the reputation of the Jordanian Private Uni versities (admiration, respect, satisfaction). From the main hypothesis, the flowing subhypothesis derives.

\section{The first sub-hypothesis:}

Ho1-1: There is no effect of statistically significant at the level of $(\boldsymbol{\alpha} \leq \mathbf{0 . 0 5})$ for the quality of website design (comprehensiveness, attractiveness) on the reputation of Jordanian Private Universities

\section{Second sub-hypothesis:}

Ho1-2: There is no effect of statistically significant at the level of $(\boldsymbol{\alpha} \leq \mathbf{0 . 0 5})$ for the quality of the information (curentness and accuracy) on the reputation of the Jordanian Private Universities

\section{Third sub-hypothesis:}

Ho1-3: There is no effect of statistically significant at the level of $(\boldsymbol{\alpha} \leq \mathbf{0 . 0 5})$ for the quality of services (reliability, responsiveness) on the reputation of Jordanian Private Universities.

\subsection{The Study Limitations}

- Spatial limitation: Six Private Universities in Jordan.

- Time Limitation: The study was applied during the period of $1^{\text {st } J u n e ~ t o ~} 30^{\text {th }}$ September 2017.

- Human limitation: The study was limited to students in scientific faculties, and they were (600) student.

- Objective limitation: To know the effect of the quality of private universities 'websites on the reputation of the Higher Education Organizations in Jordan.

\subsection{Methodology of the Study}

The study's population; is composed of students from Jordanian private universities in Amman and Irbid; (Amman Arab University, Al Isra University, Zaytoonah University, Jadra University, Jarash University and Princess Sumaya University for Technology), and they were (28512) students.

The study's sample; a sample of 1425 students were selected, i.e. $5 \%$ of the total study population.

The study's Tool; The study tool was the questionnaire, where (600) questionnaires were distributed to find out the opinion of these students on the study's subject.of the questionnaire total, (1250) were retrieved by a percentage of $(83 \%)$ which is sufficient and appropriate for the purposes of practical analysis.

Data analysis method; the Statistical Package for social sciences SPSS) was adopted for the statistical analysis and testing the hypothesis. Whereby the statistical methods used, suitable the objectives of the study and the statistical means are:

1. Descriptive Statistics, Average Arithmetic, Standard De viation, Frequencies, and Percentages (Frequency, St. 


\section{Deviation, Ratio).}

2. Simple Regression, and Multi Regression to test the validity of the study's hypotheses.

3. Stepwise Regression test to examine the gradient influence force of the study's hypotheses according to their variables.

4. Cronbach Alpha to measure the stability of the tool.

\subsection{Previous Studies}

- (Dowling, 2004) titled; Journalists' Evaluation of Corporate Reputations, aimed at describing the successful model of four indicators to measure their impact on improving the reputation of the organization. The indicators were developed based on the interviews of 25 journalists, specialized in the work of major organizations. These indicators are (market presence, organizations capabilities, performance, and social accountability), and to determine these indicators effect on the Organization's reputation, four dimensions for the Organization's reputation have been adopted, and those dimensions are (Admiration - Respect, Trust, and Reliability). The interview questions related to the organization's reputation consisted of; (Do you think the organization deserves trust? Do you think the organization deserves admiration and respect? Do you think the future work of the company can be trusted?). The study found; that these four indicators were reflecting the Organization's reputation well, and it was of a statistical significant in its relation with the variables of the Organization's reputation.

- (Lai ,2006) titled; Assessment of employees' perceptions of service quality and satisfaction with E-business. The aim of this study was to answer the question of whether the service quality gap Servqual can be used, to improve the service of E-business, also it aimed to understand the extent of the user's satisfaction of organizational applications, and its relevancy to the quality of the E-service.This study sample was 161 individuals, from six companies working in the field of electronic industry, it has relied on a model that describes basic dimensions of service quality, those dimensions includes;(reliability, responsiveness, assurance and understanding), in order to study the impact of these dimensions on the quality of E-commerce service from the point of view of the employees. The study concluded that reliability has a significant impact on quality of service, and users' satisfaction the ease of use, is one of the most important factors of users' satisfaction, which contributes to the success of the staff's service. The study also found, that reliability is an important factor for users' satisfaction, which contributes to the success of organizations' applications.

- (Lee, \&Kozar, 2006) titled; investigating the effect of website quality on E-business success: An analytical hierarchy process (AHP). The aim of this study was to examine the quality factors of the website (the standards) and the importance of those standards in the selection of the site, where AHP system was used. The study also aimed to determine the gap between what the Internet customers expect on the one hand and the evaluation of site quality, and on other hand, what managers and designers of companies expect, and the examination of the relation, between the adoption of the public's preferences of the site and the level of its performance. A field study was conducted with 156 Internet clients, and managers and designers of 34 E-Business companies, where the following three factors were emphasized on; (System's Quality, Information's Quality, Service's Quality). The study found, that each of the three factors of the site's quality was closely related to the selection of the most preferred site. The study also found that the system's quality from the point of view of Internet customers is one of the most important factors in preferring a website. Also security and the ability to navigate through the site ranked high in the preference of sites, pointing out, that organizations must do more, to make the site more navigable and safer. The results of the study also showed; that there are determinants faced by the researcher through the dimensions, which has been relied upon, and it should be re-examined in future studies.

The study of Abu-Rub (2006) titled; The framework of a model for the evaluation of the websites' quality , a study based on secondary sources to form a framework for the model of evaluating the websites' quality ( regardless of the nature of the service provided by the site), comprehensive in terms of containing the main elements for evaluation, celerity through the possibility of using numerical values to measure the indicators, and flexible in its applicability to all sites, regardless of the nature of the service provided, whether it is a commercial company, or e-government, Or financial institution, or other. The study found that the proposed framework evaluates the quality of a wide range of websites, regardless of the nature of the electronic service provided. In addition, the proposed framework can be converted to a questionnaire after giving the indicators of the evaluation elements, specific numeric values, and it can be applied easily to evaluate the quality of any website.

(Cohen2007) named; Reputation beyond the Rankings: A Conceptual Framework for Business School Research, is study aimed at building a model of the factors pointing at business reputation in the education sector. The 
researcher relied on the sources of secondary information (theoretical literature) to reach the results of the study, which were; The most important variables of the reputation of educational organizations centred around; the good feeling about educational organizations, the trust in the educational organizations, respect for and admiration of educational organizations, and the appreciation or satisfaction of educational organizations by its audience. As for the factors that raise the level of reputation of educational organizations, they were; performance, service, management, compliance with laws, citizenship, and creativity. The study recommended to follow a strategy of making good reputation for the institution, this strategy should focus on the development of the geographical area, where the educational institution located, where that focusing must be limited to that geographical area and not to expand to the state or international level. The study discerned, that focusing on a certain geographical area, and working to raise the appreciation and evaluation levels, of the educational institution in a specific geographical area, has a greater effect on improving the reputation of the education institution.

- The study of (Najem and the Almubaideen2009) titled; Electronic quality: towards a proposed model for an electronic quality dimensions. The study aimed to define the dimensions of Electronics'-quality, in order to reach a comprehensive model of Electronics'- quality. In its methodology, the study adopted the literature and studies related to the subject of the study, with the idea; that through the analyses of such literature and relating studies, the study will reach the objectives it is pursuing, which is; to introduce a comprehensive model of Total Quality Management (TQM) that can be applied on websites. The study assumption was; that Quality of service (QoS) dimensions, have become the most important in quality improvement principles, and those dimension shave been determined by five main dimensions which are; the Parables(materialistic facilitating, devices and individuals), Reliability, Responsiveness, Capability(the knowledge and skills of the service provider), Empathy and the quality gaps model, known as Servqual System, which is-according to the study- is still an effective system in the study of the quality of service.Some of the most important conclusions the study reached was; interest in quality was not precedent, but rather, a product of a development, starting with efficiency - producing the maximum can be produced, regardless of its quality-, and then that shifted to interest in quality of production -within the factory-, and thereafter the quality of the product, meaning; an interest transition from a production system to the customer. The interest in service's quality was a later stage of, i.e., a transition from commodity to service, for the transition to an economy service-based in developed economies, made the quality of service the most important. As for the suggested model of website quality, the study presented a five dimensional model consist of; the quality of the organization's website, the quality of the software, the quality of information, the quality of the diversity of E-services, and, finally, electronic ethics.

The study of (Gorla, Somers, Wong 2010) titled; Organizational impact of system quality, information quality, and service quality. The study aim was at the achievement extent of the objectives of QoS in organizational performance in organizations in relation to the variables; quality system, quality of information, and the quality of service. The questionnaire was sent by e-mail to a sample of 800 individuals, where 90 individuals responded. The study showed that QoS is the most influential variable in organizational performance, followed by quality for information and then quality system. This study contributes - in theory- in affirming the success of information systems models, through quality systems to quality information, and the influence of quality type to the organizational matters, where;

1) Quality system is a well-designed system that achieves organizational system objectives.

2) The achievement of information quality in terms of content is of high level of accuracy, comprehensiveness and relevance, and of significant impact on decision-making.

3) Quality of service depends on the providing success of services to various users, in accordance with what they expected or exceed their expectations. The study also found, that the quality of information systems; (quality system, quality of information, and quality of services) has an important effect on the organization, and the outcomes points to, that the dimensions of the quality of information systems have a significant positive effect on organizations, either directly or indirectly.

(Lange, Peggy, 2011)study titled; Organizational Reputation: A Review, aimed at clarifying the concept of the organization's reputation with its elements, in terms of management principles, from the aspects of reasons, that affect the reputation of the organization, in terms of familiarity with the organization, it has relied on the Organizations' Reputation Publications, through theoretical articles. The cars manufacturing company Toyota was chosen - a case study- for, as it is a highly reputable company, where 2.3 million vehicle have been withdrawn from the market due to a manufacturing fault. The study showed, that the idea of organizational reputation, is an intuitive and simple idea in its general form, yet it is complex when working in the field of 
researching and investigating management. The study identified three perceptions of reputation which are; that reputation consists of familiarity with the organization, beliefs of what to expect from the organization in the future, and the preference level of the organization. The study also produced experimental results in management principles regarding the causes or the effects, that affect the reputation of the organization. The researchers concluded by drawing the attention to some important trends to research in the future, whereby it achieves organizational reputation through multiple dynamic dimensions to define a model for their foundations, and the ir impact, where it is more comprehensive than the monolithic models previously presented.

(Barron and Rolfe, 2011) titled; Measuring Reputation: Corporate Appeal, Political influence and Regulation. This study aimed at measuring the reputation of organizations through the its mission, the influence of policies and constitution. To measure reputation, the study relied on the variables of; admiration, trust, reliability, Satisfaction, and social responsibility. The study also aimed to expand the concept of reputation, to include theoretical dimensions, while at same time developing, and adopting new measuring tools for reputation, enables researchers to study it accurately. The study was based on field social survey, by means of a decimal scale questionnaire -from 0; lowest estimates of the reputable variables, up to 10 , the highest estimate of those variables- for a sample of 1,400 British citizens, and 6000 German citizens, to measure the reputation of 15-20 major companies, some of which; HBSC and Vodafone. The study concluded, that the organization's reputation is not just a competition for the organization's fans, and should not be theoretical or measured on a theoretical basis, because reputation is a crucial source, the company strive to achieve, due to the organization's profitability importance and its survival.

It has also shown that reputation is not just a positive image, or a trademark, although it is important for the profitability of organizations, but it includes measures, based on measurable scientific principles. The study indicated, that the political influence of a company in England, is not related to good reputation, with the exception of engineering and manufacturing companies, and British citizens do not distinguish between organizations on the demand for regulation basis, where some organizations and industries are seen as a structured enough or even more organized, while others consider that they require higher levels of government intervention.

- (Al-Shara and Al-Zoubi 2017) titled; Effect of university websites on foreign students in their selection for their academic specialization: A field study on a sample at the universities of Jidra and Amman Arab University. The aim of this study is to identify the impact of the Jordanian uni versities' websites, on foreign students in relation to their choice of faculties. To answer the study hypotheses, a questionnaire was designed to measure these hypotheses, which consisted of (22) paragraphs, divided on the three pillars; equipment and materialistic capabilities, educational services, the university's academics and administrates. For the study's community, is made of all the foreign students at both universities, a random simple sample of 77 students was chosen. The questionnaire was distributed to the sample and then analysed by SPSS. The results showed that the private universities subject of the study, uses websites to promote their products, and that most of the students, sample of study, benefited from the marketing services of the university websites in order to register, The study recommended the necessity of the Jordanian private universities to correlate between what is announced on their websites and what is actually in reality on the ground.

\section{The Theoretical Framework of the Study}

\subsection{Universities'Websites}

\subsubsection{Concept of Websites}

Websites are a set of web pages interconnected with each other in a hyperlink way to cover a particular topic or represent the organization's activities, products, and services, in a way that ensures, that its goals are achieved through electronic presence (Kelly, 2005:p 41), because it provides all the characteristics of the organization in a strategic framework of understanding of all the elements of critical success or failure in E-business. (Najm, 2010, pp482).

\subsubsection{Importance of Websites}

The importance of the websites lies in it being a private space for business and governmental services, and became a major portal for organizations and governments to provide services to all customers. (Carey, 2001: p 5)

\subsubsection{Dimensions of Websites' Quality}

some of the key dimensions of quality pointed by Nemours researchers are; 
- Comprehensi veness: Information about the services or products to include what the visitor needs, and this is one of the most important elements of quality, which must be taken into account when evaluating the websites, and the services provided. (DeLone\& McLean, 2003: pp10)

- Responsiveness: It is the response of the service provider to customers' requests, with accuracy and transparency as expected, and to answer customer inquiries and comments, with an acceptable speed as quickly as the customer expects. (Ahmad, 2009, pp95)

- Reliability: is the confidence in the quality and efficiency of the service provided, for the degree of accepting the service is highly dependent on the ability to deliver performance and satisfactory service for a period. (Aladwani \& Palvia, 2002: pp469)

- Information accuracy: This indicator can be measured using the following checklist: the number, thechecklist, accuracy of information on the website, absence of grammatical or linguistic errors on the website, sources of information on the website are verified.(Barnes and Vidgen, 2001: pp114)

- Currentness: currentness of information on the website. This indicator can be measured using the following checklist: number, checklist, up-to-date information on website, and number of updates over a specified period of time, clarity of user's last time update. (Barnes and Vidgen, 2001: pp114), (Mich, 2003: pp39)

- Attractiveness: it is an absolute personal dimension for the quality irrelevant to one's function, but in the general form, appearance, touch, sound and taste of the product and ultimately, it depends on the personal technology level of the consumer. (Al Hilali, 2009, pp478)

\subsubsection{Quality of Information}

In spite of the increasing information, many organizations feel that they are in real crisis. In the report published by The Economist, it was noted, that information is everywhere, and its outcomes of knowledge are not always materialized, and there is a lot of inaccurate and unreliable information, for when the information are of high quality and accuracy, it become a factor in in reducing uncertainties, and increase the level of knowledge (The Economist, 2005: pp1).

\subsection{Quality of E-Services}

\subsubsection{The Concept of E-services Quality}

it means the extent to which a website facilitates the sale, purchase and delivery of services and products efficiently and effectively(Zeithmal, et al., 2000: 363), and it is; the customers evaluation for the services provided to them by interacting with the service(Praeg \& Spath,2010.pp32), and it is also; the achievement of efficient mobility on the network, and increasing the volume of data and information provided to the customer (Najm, 2010, p. 472), and the customer can evaluate the website according to the degree of browsing enjoyment, during his visit to the website(Rashid, 2008, pp66). (Pavlichev \& Garson, 2004: pp169) declared; that E-services are primarily initiated by governments (E-Governments), out individuals and institutions needs to deal with the governments to gain access to services with less effort, time and cost, and added, that E-services may also include E-commerce and everything on the Internet.

\subsubsection{The Concept of Reputation}

Reputation is a public assessment of the organization's ability to meet the recognised needs of the public (Pollock, 2003:pp46), and it is the impression of the consumers about the organization, in connection to its products, policies and terms, where the more positive their opinion is, they are keenest to maintain the relationship and strengthen it. The organization might got associated with certain reputation, that emerges in the minds of the end consumers, through which it obtains a competitive advantage that attracts the public (Sobnosky, 1999: 25).However, the organization is expected to gather the views of the consumers, to assess their strengths and weaknesses, and then carry out communication activities that improves its reputation and image, regarding its various activities in the consumers' minds. (Lange, 2011: pp155). Some of the benefits reputation grants the organization are; improving its image, attracting and retaining employees, attracting consumers, and building a long relationship with them. (Fombrun, 2000:pp85), and reputation remains one of the causes for success, as (Ewing, 1999: pp121) noted, that although good reputation may help organizations to succeed, it is not a warranty for an overall success.

\subsubsection{Factors of the Interest in Organizations 'Reputation}

Organizations that do good work for their reputation emphasize on the following factors: 
Appearance and Excellence: No matter how good the organization is, there is no real reputation without its appearance and its name popularity. Most analyses confirm, that the awareness of the organization or the affinity between the public and the organization, positively affects its reputation, and it is noticeable, that reputable organizations are the most visible ones through the media, for taking interest in communicating with all shareholders and the public, increases the perception of the organization as genuine and credible. (Fombrun, 2004: pp53)

Transparency: Organizations should have openness and transparency in their work field, for the organizations develop and strengthen their reputation, when they are transparent in running their affairs. On the contrary, organizations that avoid communicating with the public, do not provide minimum information about their internal structures ,and avoids revealing what it does and how it is done, usually the public opinion of its reputation reduced public (Fombrun, 2004: pp51).

\section{Classification standards of reputable organi zations}

There are standards for the distinguish characteristics of reputable organizations, these standards are cantered around eight characteristics as follow: quality of management, ability to develop; (development of internal infrastructure or services, growth of revenues, etc.), quality of product or service, (it is possible to put in place a standards to masseur theQoS), retaining important people, the sound financial position, the optimal use of assets and possessions of the organization, degree of innovation (degree of services' innovation and operations provided by organizations), and its friendliness toward the environment.(Martin, Hetrick, 2006: pp5)

Organizations that have these characteristics are well-reputed, because such characteristics, conform a popular impression for the organization's costumers, which makes a distinctive image or perception of the organization. (Martin, Hetrick, 2006:pp229)

\subsubsection{Reputation's Metrics}

Reputation is a tool that can be used for competing, where performance is required to be consistently excellent in order to gain the desired reputation, and thus serve as an incentive for accurate performance at all levels in the organization. The most famous metric for the organization's reputation according to the annually published magazine Fortuneis; the most exciting and impressive organization. This metric, rely on a reputation model consist of eight elements(Barron, and Rolfe,2011:pp2); Creativity, management of individuals, use of organizational assets, social responsibility, quality of management, financial position, long-term investments, and quality of the product or service that the organization provide.

Many scholars and researchers have pointed out to the reputation's standards in the organizations, where mostly were focused on the impression, and the way the organization's customers and shareholders feels, and they concentrated on emotional appeal, vision, leadership, financial performance, work environment, social responsibility, products and services. Some researchers cited four elements to measure the organization's reputation, and those elements are; admiration, respect, trust, reliability (Dowling, 2004: pp198).(Barron and Rolfe2011: pp3) pointed to five dimensions of reputation and they are; admiration, trust, reliability, satisfaction, and social responsibility.(Kotler 2001: pp36) identified satisfaction as an indication for the recognised performance by the customer, for in case of the expected performance failure, the customer will be in a discontent or displeasure state, and if the performance is coincide with expectation, the customer will feel joyfulness and content, but in a when performance exceeds what is expected by the, the customer position will evolve from satisfaction to the loyalty to the organization, and will be closely connected to it and this is the state that the organizations are looking for.

\section{The Practical Framework of the Study}

\subsection{Exhibiting the Results and the Hypotheses'Test}

\subsubsection{The Study's Main Hypothesis}

There is no statistical significant effect on the quality of the website in terms of its dimensions; (the design quality of website, quality of information, quality of services) on the reputation(admiration, respect, satisfaction) of the Jordanian private universities at the level of $(\alpha \leq 0,05)$.

In order to examine the hypothesis, the multi regression of the study's sample views' averages was used to determine the extent of the statistical significant effect at the level of $(\alpha \leq 0,05)$ for the quality of the website according to the dimensions; (the design quality of website, quality of information, quality of services), on the reputation(admiration, respect, satisfaction) of the Jordanian private universities, and Table (1) shows the results. 
Table 1. Multi regression of website quality in university reputation

\begin{tabular}{ccccccc}
\hline & $\begin{array}{c}\text { Significance's } \\
\text { Level }\end{array}$ & $\begin{array}{c}\mathbf{R}^{2} \\
\text { Coefficient of Determination }\end{array}$ & $\begin{array}{c}\mathbf{R} \\
\text { correlation } \\
\text { coefficient }\end{array}$ & $\begin{array}{c}\text { Calculated } \\
\mathbf{F}\end{array}$ & $\begin{array}{c}\text { Tabular } \\
\text { F }\end{array}$ & $\begin{array}{c}\text { DF } \\
\text { Frity }\end{array}$ \\
\cline { 2 - 7 } $\begin{array}{c}\text { Febsite } \\
\text { Webom's degree }\end{array}$ & $\mathbf{0 , 0 0 0}$ & $\mathbf{0 , 3}$ & $\mathbf{0 , 5}$ & $\mathbf{1 3 1 , 8}$ & $\mathbf{2 , 1}$ & $\mathbf{3}$ \\
\hline
\end{tabular}

The results of the statistical analysis in Table (1) showed that there is a statistical significant effect for the quality of the website on the reputation of the Jordanian private universities, for the correlation coefficient $(R)$ was $(0,5)$ at the level of $(\alpha \leq 0,05)$, and as for the coefficient of determination $\left(R^{2}\right)$ it was $(0.3)$, which means; that the value of $(40 \%)$ of the changes in the reputation of the Jordanian private universities, is the result of the change in the quality of the website, this result is reinforced by the increase in the value of (F). Therefore, we reject the null hypothesis and accept the alternative hypothesis, meaning; that there is a statistical significant effect for the quality of the website on the reputation of the Jordanian private universities. Based on such result we conclude, that the importance of websites quality in improving the reputation of universities, and this importance stems from the evolution of information technology, because students are using the information technology to access data, which is of great importance to the universities' websites, and because universities' websites is the students' overlooking portal at the universities, and it is the first glimpse of the university the students see, thus the website works to form impressions in their minds, which affects the reputation of the universities from stand point of the study's sample.

\subsubsection{Stepwise regression test for the quality of websites}

In order to determine the most influential dimension of the quality of the website (quality of services, quality of information, and quality of website design) on the reputation of Jordanian private universities, the stepwise regression was used for the study's sample views' averages at the statistical significance level $(\alpha \leq 0,05)$, and Table (2) shows the test results.

Table 2. Stepwise regression test for the quality of the university website on the reputation of universities

\begin{tabular}{lllll}
\hline Dimensions of the Website & F & R & $\mathbf{R}^{2}$ & Significance's Level \\
\hline Quality of Services & 577.067 & 0.522 & 0.321 & $\mathbf{0 . 0 0 0}$ \\
Quality of Information & 353.495 & 0.615 & 0.363 & $\mathbf{0 . 0 0 0}$ \\
Quality of the Website Design & 257.344 & 0.625 & 0.388 & $\mathbf{0 . 0 0 0}$ \\
\hline
\end{tabular}

Table (2) indicates that the quality of services has had the greatest impact on the reputation of the Jordanian private universities. The value of the test (F) was (577.067) and an explanatory capacity (32.1\%). This means; that $(32.1 \%)$ of the changes in the reputation of Jordanian universities, are resulting from the change in the quality of services. Though as forthe quality of the information, we note that the value of the test (F) has reached $(353,495)$, and the explanatory capacity of the variables of the quality of services, and the quality of information has reached $(36.3 \%)$. We also note that the value of the test $(F)$ for the quality of the design has reached $(257,344)$ and the explanatory capacity for the variables of quality of service, quality of information and quality of the website design has reached (38.8\%).

To arrive at more detailed results, this hypothesis was divided into sub-hypotheses that were tested as follows:

The first sub-hypothesis: There is no statistical significant effect for the quality of the website design (comprehensi veness, attractiveness) on the reputation of Jordanian private uni versities at the level of ( $\alpha \leq$ 0, 05).

Table 3. Simple regression of university's website design quality for university's reputation

\begin{tabular}{lccccccc}
\hline $\begin{array}{l}\text { Design's Quality of } \\
\begin{array}{l}\text { Universities' Website } \\
\text { (comprehensiveness, }\end{array}\end{array}$ & $\begin{array}{c}\text { Significance's } \\
\text { Level }\end{array}$ & Calculated F & Tabular F & $\mathrm{R}$ & $\mathrm{R} 2$ & $\begin{array}{c}\beta \\
\text { Regression } \\
\text { coefficient }\end{array}$ & $\begin{array}{c}\text { The result } \\
\text { of the null } \\
\text { hypothesis }\end{array}$ \\
\cline { 2 - 9 } attractiveness ) & $\mathbf{0 , 0 0 0}$ & 366.960 & $\mathbf{2 , 4}$ & 0.445 & 0.221 & $\mathbf{0 , 1 7 7}$ & ejected \\
\hline
\end{tabular}

Table 3. Indicates that there is a statistical significant effect for the quality of the website design on the reputation of the Jordanian private uni versities. The value of(F) reached(366.960) and at a moral significance of $(0,000)$, and therefore we reject the null-hypothesis and accept the alternative hypothesis, which means; that there is a statistical significant effect of the website design quality (comprehensiveness, attractiveness) on the reputation of Jordanian private universities at the level of $(\alpha \leq 0,05)$.The comprehensiveness design of the website and its ability to provide adequate links and attractiveness that drew the attention of students, and having a better view of the university in general, leads to a better reputation for those universities. This means; that the design of the website contributes to raise the level of admiration and respect for the university, and raise the proudness level of 
students in their universities, through the design attractiveness and comprehensiveness of all the links that suit the students.

Second sub-hypothesis: There is no statistical significant effect on the quality of information (currentness, accuracy of information) on the reputation of Jordanian private universities at the level of $(\alpha \leq 0,05)$.

Table 4. Simple regression of university website information quality for the reputation of universities

\begin{tabular}{llllllll}
\hline $\begin{array}{l}\text { Quality of } \\
\text { provided } \\
\text { information }\end{array}$ & $\begin{array}{l}\text { Significance's } \\
\text { Level }\end{array}$ & Calculated F & Tabular F & $\mathrm{R}$ & $\mathrm{R}^{2}$ & $\begin{array}{l}\text { Regression } \\
\text { coefficient } \beta\end{array}$ & $\begin{array}{l}\text { The result of the } \\
\text { null hypothesis }\end{array}$ \\
\cline { 2 - 7 } $\begin{array}{l}\text { Universities } \\
\text { Website } \\
\text { (currentness }\end{array}$ & $\mathbf{0 , 0 0 0}$ & 430.930 & $\mathbf{2 , 1}$ & 0.470 & 0.220 & $\mathbf{0 , 1 8 8}$ & Rejected \\
$\begin{array}{l}\text { and accuracy } \\
\text { of } \begin{array}{l}\text { the } \\
\text { information) }\end{array}\end{array}$ & & & & & & & \\
\hline
\end{tabular}

Table (4) shows that there is a statistical significant effect for the website's quality of the information (currentness and accuracy of the information) on the reputation of the Jordanian private universities, asthe value of (F)was (430.930), which is higher than its tabular value, and at a significant level of (0.00), and which is less than the specified value of $(\alpha \leq 0,05)$.Therefore, the null hypothesis is rejected and we accept the alternative hypothesis, and this means; that there is a statistical significant effect for the quality of the information (currentness and accuracy of the information) on the reputation of the Jordanian private universities at the level of $(\alpha \leq 0,05)$, where by the currentness and the accuracy of information, is of the most important purposes of visiting the website, for the student who visits the university website, in order to search for information, it becomes more important when it is accurate and up-to-date, and therefore, it means that the quality of information contribute to theperception improvement of the University, and thus improve its reputation.

The third sub-hypothesis: There is no effect for the quality of services (reliability, responsiveness) on the reputation of Jordanian private universities at the level of $(\alpha \leq 0,05)$.

Table 5. Simple regression forthe quality of website's services effect on the reputation of universities

\begin{tabular}{lccccccc}
\hline $\begin{array}{l}\text { Quality of } \\
\text { services } \\
\text { provided at }\end{array}$ aniversities, \\
$\begin{array}{l}\text { Website } \\
\text { (reliability, } \\
\text { responsiveness) }\end{array}$ & $\begin{array}{c}\text { Significance's } \\
\text { Level }\end{array}$ & Calculated F & Tabular F & $\mathrm{R}$ & $\mathrm{R}^{2}$ & $\begin{array}{c}\text { Regression } \\
\text { coefficient } \beta\end{array}$ & $\begin{array}{c}\text { The result of } \\
\text { the null } \\
\text { hypothesis }\end{array}$ \\
\cline { 1 - 7 } & $\mathbf{0 , 0 0 0}$ & 570.069 & $\mathbf{2 . 1}$ & 0.470 & 0.311 & $\mathbf{0 . 3} 10$ & Rejected \\
\hline
\end{tabular}

Table (5) indicates that there is a statistical significant effect for the quality of the website's services on the reputation of the Jordanian private universities, as the value of (F) was (570.069), which is higher than the tabular value, and at a significant level of (0.00), and less than the specified value of $(\alpha \leq 0,05)$, and therefore, we reject the null- hypothesis and accept the alternative hypothesis. which means; that there is a statistical significant effect for the quality of services (reliability, responsiveness) on the reputation of Jordanian private universities at the level of $(\alpha \leq 0,05)$, where is the importance of websites' services, lies in their reliability and responsiveness to what students need, for students seek answers to their inquiries through the uni versity website, which may make them feel satisfied, admired and respected. And respond to what students need, students are seeking to answer their queries through the website University, which may make them feel satisfied of, admire, and respect for the university.

\section{Conclusions and Recommendations}

\subsection{Results}

The results of the study indicated that:

1. The quality of web design (comprehensiveness and attractiveness), quality of information (currentness and accuracy) was high.

2. The quality of services (reliability and responsiveness) provided by the University's website was at an medium level and did not reach the desired level.

3. The quality of the information provided by university websites was at an appropriate level.

4. The quality of the web design was of a high standard and met the expectations of the students. Also, the design of the webpages of the universities' websites has the attractiveness, the ease of navigation and access to the 
required information.

5. Universities enjoy a good reputation, and they are admired, respected, satisfying by and for students. As study found, that the admiration, respect, and satisfaction achieved, reflects the positive reputation of the universities, also the study showed the following:

A. Universities' students feels the admiration for their universities, loyalty, and keenness to Describe the University with the best descriptions, as they also have shown, that they are proud to be associated with their university.

B. University students feel the respected for their universities, and that the website enhances that sense, as well as their positive perception toward the services and information provided through these websites.

C. The study showed that the university's website, provides services that are relatively superior to traditional services, and provides the required information on the website, although some of the websites of these universities do not provide electronic registration services, in a way for traditional registration to be a voided.

6. The study also found; that there is an effect for the quality of university's websites on elevating these universities' reputation. In first place, the quality of services has the higher impact, the quality of information took the second place, and the quality of website design came third, for the conceptual image in the mind-set of students' about their universities,(Reputation) is formed from using websites that consist of services, design and the presented information, which contributes to the circulating of positive notions and narratives about universities among students.

\subsection{Recommendations}

Based on the findings, the study reached the following recommendations:

1. Jordanian universities should pay more attention to their websites, in terms of the quality of these sites. It is noted; that despite the importance of these sites, there is a lack of quality of contents, especially with regard to registering through the website, as the study has found, that the registration services are not available for some universities.

2. The necessity to improve the quality of services provided at the Jordanian private universities, as the results of the study indicated, that the quality of their services was moderate, which may affect the reputation of these universities negatively in the future.

3. To conduct further studies concerning the quality effect of these websites on improving the universities' reputation, especially that the researcher noticed the scarcity of Arabian studies related to the university's websites' quality, including new dimensions has not been covered by this study, such as; other dimensions of quality, confidentiality, safety, etc., and also, it could be from the point of view of universities 'employees (internal quality).

4. This study opens the door for researchers, to carry out researches based on its findings, regarding the factors affecting the reputation of universities. It also opens the door for researchers to conduct researches related to the quality of E-services from other points of view such as employees, lecturers and others.

\section{References}

Aladwani, A. M., \& Pal via, P. C. (2002). Developing and validating an instrument measuring user-perceived web quality. Information and Management, 39(6), 467-476. https://doi.org/10.1016/S0378-7206(01)00113-6

Ali, A. Z. (2016). Electronic Advertising, University Book House, UAE.

Barnes S., \&Vidgen R., (2001). Assessing the Quality of Auction WebSites, in Proceedings of the 34th International Conference on System Sciences.

Barron, D., \& Rolfe, M. (2011). Measuring Reputation: Corporate Appeal, Political Influence and Regulation, (Unpublished), Oxford University, Centre for Corporate Reputation.

Carey P. (2001). Creating Web page with HTML, (2nd Ed.), Course technology.

Cohen, D. V. (2007), Reputation beyond the Rankings: A Conceptual Framework for Business School Research, College of Business Administration, Florida International University, Miami, FL, USA. Corporate Reputation Review, 10(4), 278-304. https://doi.org/10.1057/palgrave.crr.1550055

DeLone, W. H., \& McLean, E. R. (2003), The DE Lone and McLean model of information systems success: a ten-year update. Journal of Management Information Systems, 19(4), 9-30. https://doi.org/10.1080/07421222.2003.11045748 
Dowling, G. R. (2004). Journalists' Evaluation of Corporate Reputations. Corporate Reputation Review, 7(2), 196-205. https://doi.org/10.1057/palgrave.crr.1540220

Ewing, M., Caruan, A., \& Loy, E. (1999). Corporate reputation and perceived risk in professional engineering services. In Corporate Communications: An International Journal, 4(3), 121-128. https://doi.org/10.1108/13563289910288320

Fombrun, C. J., \& Van Riel, C. B. M. (2004). Fame and fortune: How successful companies build winning reputations. Englewood Cliffs, NJ: Prentice-Hall.

Fombrun, C., Gardberg, N., \& Barnett, M. (2000). Opportunity Platforms and Safety Nets: Corporate Citizenship and Reputational Risk. Business and Society Review, 105(1), 85-106. https://doi.org/10.1111/0045-3609.00066

Gorla, N., Somers, T. M., \& Wong, B. (2010). Organizational impact of system quality, information quality, and service quality. Journal of Strategic Information Systems, 19(3), 207-228. https://doi.org/10.1016/j.jsis.2010.05.001

Kelly, B., \& Vidgen, B. (2005): A Quality Framework for Website Quality User Satisfaction and Quality Assurance, Available: (www.ukoln.ac.uk).

Kotler, P. (2001). Marketing Management Analysis Planning, Implement and control, India, prentice Hall, Inc.

Lai, J. Y. ( 2006). Assessment of employees' perceptions of service quality and satisfaction with e-business. $\begin{array}{lllll}\text { International Journal Human-Computer } & \text { Studies, } & \text { 64(5), }\end{array}$ https://doi.org/10.1016/j.ijhcs.2006.04.007

Lange, D., Lee, P. M., \& Dai, Y. (2011). Organizational Reputation: A Review. Journal of Management, 37(1), 153-184. https://doi.org/10.1177/0149206310390963

Lee, Y., \& Kozar, K. A. (2006). Investigating the effect of website quality on e-business success: An analytic hierarchy process (AHP) approach. Decision Support Systems, 42(3), 1383-1401. https://doi.org/10.1016/j.dss.2005.11.005

Martin, G., \& Hetrick S. (2006). Corporate Reputations, Branding and People Management: A Strategic Approach to HR (Advanced HR Practitioner), Butterworth-Heinemann, Elsevier Linacre House, Jordan Hill, Oxford OX2 8DP, UK.

Mich, L., \& Franch, M., L. G. (2003). Evaluating and designing the quality of Web sites. Journal IEEE Multimedia, 10(1), 34-43. https://doi.org/10.1109/MMUL.2003.1167920

Pavlichev, A., \& Garson, G. D. (2004). Digital government: principles and best practices, Idea Group Inc (IGI). https://doi.org/10.4018/978-1-59140-122-3

Pollock, T. G., \& Rindova, V. P. (2003). Media legitimation effects in the market for initial public offerings. Academy of Management Journal, 46(5), 631-642. https://doi.org/10.2307/30040654

Praeg, C. A., \& Spath, D. (2010). Quality management for IT service "Perspectives on business and process performance", USA.

Sobnosky, K. J. (1999). The Value-Added Benefits of Environmental Auditing in Environmental Quality Management, 9(2), 25-32.

The Economist (2005). Know How: Managing Knowledge for Competitive Advantage, The Economist Intelligence Unit, p1.

The website of the best Arab and international universities www.webometrics.info

Zeithmal, V. A., Parasuraman, A., \& Malhotra, A. (2000). A Conceptual framework for understanding e-service quality: Implications for future research and managerial practice, Marketing Science Institute, Working Paper report no.00-115.

\section{Copyrights}

Copyright for this article is retained by the author(s), with first publication rights granted to the journal.

This is an open-access article distributed under the terms and conditions of the Creative Commons Attribution license (http://creativecommons.org/licenses/by/4.0/). 